\title{
Synthesis, Characterization and Antimicrobial Activity of some Metal Complexes Derived from Thiazole Schiff Bases with In-vitro Cytotoxicity and DNA Cleavage Studies
}

\author{
Shambuling Karabasannavar ${ }^{1,2}$, Parvati Allolli ${ }^{3}$, Irfan N. Shaikh ${ }^{4}$, Basavaraj M. Kalshetty ${ }^{5 *}$ \\ ${ }^{1} \mathrm{R} \& \mathrm{D}$ centre, Bharathiar University, Coimbatore. Tamilnadu, INDIA. \\ ${ }^{2}$ Department of Chemistry, BGMIT Mudhol, Karnataka, INDIA. \\ ${ }^{3}$ Department of Pharmaceutical chemistry, Karnataka State Women University, Bijapur. Karnataka, INDIA. \\ ${ }^{4}$ Department of Chemistry, SECAB Institute of Engineering \& Technology, Vijayapur, Karnataka, INDIA. \\ ${ }^{5}$ Department of chemistry, BLDE's Science College Jamkhandi, Bagalkoti, Karnataka, INDIA.
}

\begin{abstract}
Five metal complexes with Schiff-base ligand, 3-((4-phenylthiazol-2-ylimino) methyl)-2hydroxybenzoic acid were synthesized with metal ions such as $\mathrm{Cu}(\mathrm{II}), \mathrm{Co}(\mathrm{II}), \mathrm{Ni}(\mathrm{II}), \mathrm{Cd}(\mathrm{II})$ and $\mathrm{Zn}(\mathrm{II})$. The reaction likely proceeds via condensation of 2-amino-4-phenyl thiazole with 3-aldehydosalicylic acid and characterized by elemental analysis and various spectral studies like FT-IR, ${ }^{1} \mathrm{H}$ NMR, ESI mass, and TGA/TDA and molar conductance studies. The spectral results revealed bidentate $\mathrm{O}-\mathrm{O}$ donor and forms the complexes having square planar geometry. The antibacterial and antifungal activity of the ligand and its metal complexes was found based on the determination of minimum inhibitory concentrations. The brine shrimp biological assay was also carry out to study the In vitro cytotoxicity properties for the ligand and its metal complexes against Artemia salina. Moreover, DNA cleavage experiments revealed that the $\mathrm{Cu}$ (II), Co (II) and $\mathrm{Zn}$ (II) complexes exhibited remarkable DNA cleavage activities via the generation of hydroxyl radical.
\end{abstract}

Key words: Thiazole, Schiff base, Antimicrobial, DNA cleavage, In-vitro cytotoxicity.

\section{INTRODUCTION}

The chemistry of the Schiff base ligands and their metal complexes evoke much current interest and encompasses a vast area of organometallic compounds and various aspects of bioinorganic chemistry. ${ }^{1}$ Schiff bases are considered as privileged ligands because they are easily prepared by condensation of aldehydes or ketones with amines and are able to stabilize different metals in various oxidation states. ${ }^{2,3}$ The importance of Schiff base complexes for bioinorganic chemistry, biomedical applications, supramolecular chemistry, catalysis and material science, separation and encapsulation processes, and formation of compounds with unusual properties and structures has been well recognized and reviewed. ${ }^{4}$ Large numbers of Schiff bases have shown to exhibit a wide range of biological activities, including antitumor ${ }^{5}$ anti-bacterial ${ }^{6,7}$ fungicidal ${ }^{8}$ and anticarcinogenic. ${ }^{9}$ properties. On the other hand, coordination compounds with heterocyclic Schiff base ligand has attracted much attention of the chemist in current years to find applications as potential drugs, ${ }^{10,11}$ due to the presence of multifunctional groups. ${ }^{12,13}$ The excessive attention of synthesizing determined broad range of $\mathrm{N}$ and $\mathrm{S}$ chelating ligands as thiazole molecule have attracted significant interest and gained special attention not only in structural chemistry of their multifunctional coordination modes but also showed importance in medicinal and
Submission Date: 07-02-2017; Revision Date: 18-03-2017; Accepted Date: 30-03-2017

DOI: $10.5530 / \mathrm{ijper.51.3.77}$ Correspondence: Basavaraj M. Kalshetty, Department of chemistry, BLDE's Science College Jamkhandi, Bagalkoti, Karnataka, INDIA Tel: +91-8353-220003; Fax: +91- 8353-220183 E-mail: drkalshetty@gmail. com

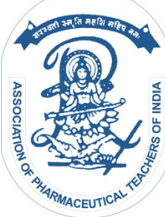

www.ijper.org 
pharmaceutical field. ${ }^{14}$ This is because thiazoles have a great pharmacological activity. Many thaizole derivatives such as sulfathiazole, ritonvir, abafungi, blemycin and tiazofurin are well known as potent biologically active compounds. ${ }^{15,16}$ Moreover, thiazoles are very important building blocks in medicinal chemistry and can be found in numerous natural products and biologically important compounds including anti-microbial, antiinflammatory, anti-hypertensive, anti-HIV, anticancer and cytotoxic activity that can be well illustrated by the large number drugs in the market containing the moiety. ${ }^{17,18}$ Thiazole ring also found applications in polymer, liquid crystals, photo-nucleases, fluorescent dyes, insecticides and antioxidants. ${ }^{19,20}$ Their transition metal complexes have attracted a great deal of interest largely due to their ability to interact with DNA molecule. ${ }^{21}$ These complexes that can bind or cleave DNA molecule at exact sites, plays an important role in genomic investigation and in photodynamic therapy against cancer. ${ }^{22} \mathrm{It}$ is well known that some coordination compounds can inhibit the growth of cancer cells by binding and damaging DNA. ${ }^{23}$ Intrigued by the above observations and in continuation of our ongoing research work on synthesis and characterization of Schiff base ligands and their metal complexes, hereby we report the synthesis of a novel Schiff base ligand 3-((4-phenylthiazol-2-ylimino) methyl)-2-hydroxybenzoic acid and its metal complexes, their characterization by different spectroscopic techniques and their antibacterial, antifungal, DNA cleavage and in vitro cytotoxicity property.

\section{MATERIALS AND METHODS}

All chemicals employed in synthesis were used as analytical extra-pure grade and solvents are purified according to the literature methods. ${ }^{24}$ The melting points of newly synthesized compounds are determined in open glass capillary tubes and are uncorrected. Purity of the compounds was checked by TLC and the spots observed in iodine vapours. The presence of metal and chlorides contents was determined according to standard procedure. ${ }^{24}$ Compound, 2 amino- 4- phenyl thiazole were prepared according to reported method. ${ }^{25}$

\section{Physical Measurements}

IR spectra of the new synthesized Schiff base and its metal complexes were recorded in $\mathrm{KBr}$ pellets on a Perkin-Elmer FT-IR instrument in the range 4000-250 $\mathrm{cm}^{-1} .{ }^{1} \mathrm{H}$ NMR spectra were recorded on Bruker Avance II $400 \mathrm{MHz}$ NMR spectrometer in DMSO-d6 using TMS as an internal standard. ESI mass spectra were recorded by electrospary ionization (ESI) on a waters micro mass Q-TOF micro spectrometer. Thermal anal- ysis of the complexes was carried out on a Perkin-Elmer STA 6000 thermal analyzer in static air with a heating rate of $20^{\circ} \mathrm{C} / \mathrm{min}$. Molar conductance was measured on the ELICO (CM-185) conductivity bridge using $10^{-3} \mathrm{M}$ solution in dry DMF by dip type conductivity cell fitted with a platinum electrode. Elemental analysis $(\mathrm{C}, \mathrm{H}$ and N) were performed on a Vario EL III CHNS analyzer.

\section{Synthesis of Schiff base ligand}

Synthesis of Schiff base ligand was summarized in Scheme 1. An equimolar mixture of 2-amino-4-phenyl thiazole $(0.01 \mathrm{~mol})$ and 3-aldehydosalicylic acid $(0.01$ $\mathrm{mol})$ with a catalytic amount of glacial acetic acid (1-2 drops) in ethanol (25 ml) was refluxed on a water bath for about 4-5 hrs. The reaction was monitored by thinlayer chromatography. The brown solid separates were filtered, washed with little ethanol, dried and recrystallized from alcohol. Melting point was $\left(180-190^{\circ} \mathrm{C}\right)$ yield $72 \%$; molecular weight (324) g per mol $\mathrm{C}_{17} \mathrm{H}_{12} \mathrm{~N}_{2} \mathrm{O}_{3} \mathrm{~S}$, Elemental analysis: found (calc.): C 63.20(63.15), H 3.36(3.73), and N 8.57 (8.60).

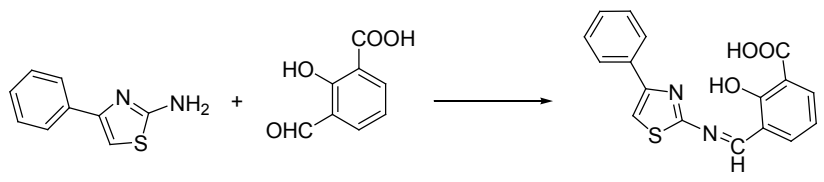

Scheme 1: Synthesis of Schiff base ligand

\section{Syntheses of the Schiff base metal complexes}

An ethanolic solution $(25 \mathrm{ml}, 0.01 \mathrm{~mol})$ of the appropriate metal chloride $\mathrm{MCl}_{2}(\mathrm{M}=\mathrm{Co}, 2.378 \mathrm{gm} ; \mathrm{M}=\mathrm{Ni}$, $2.377 \mathrm{gm} ; \mathrm{M}=\mathrm{Cu}, 1.705 \mathrm{gm}, \mathrm{M}=\mathrm{Zn}, 1.363 \mathrm{gm}, \mathrm{M}=\mathrm{Cd}$, $2.013 \mathrm{gm})$ was added to an ethanolic solution $(30 \mathrm{ml})$ of the Schiff base. The reaction mixture was refluxed for about 4 hrs, during which no solid separated out. An aqueous alcoholic solution of sodium acetate $(0.5 \mathrm{gm})$ was added to the reaction mixture to maintain a $\mathrm{pH}$ about 6.0-7.0 and reflux was continued for about an hour. The reaction mixture was transferred into the distilled water. The separated solid complexes was collected by filtration, washed with minimum quantity of distilled water and dried in a vacuum over anhydrous calcium chloride in desiccators.

\section{Pharmacology}

\section{Antimicrobial activities}

The biological activities of the synthesize Schiff base and its metal complexes were studied under antibacterial and antifungal activities by disc and well diffusion method respectively. The In vitro antibacterial activities of the compounds be tested against two Gram positive Bacillus subtilis (MTCC 736) and Staphylococcus aureus 
(MTCC 3160) and two gram negative Salmonella typhi (MTCC 98) and Escherichia coli (MTCC 46) bacteria. The In vitro antifungal an activity was carried out against Candida albicans (MTCC 227), Cladosporium oxysporum (MTCC 1777) and Aspergillus Niger (MTCC 1881) fungi. ${ }^{27,28}$ The stock solution of the test chemicals $\left(1 \mathrm{mg} \mathrm{mL}^{-1}\right)$ was prepared by dissolving $10 \mathrm{mg}$ of the each test compound in $15 \mathrm{ml}$ of distilled DMSO solvent. The different concentration of the test compounds $\left(100,75,50,25\right.$ and $\left.12.5 \mu \mathrm{g} \mathrm{mL}^{-1}\right)$ prepared by diluting the stock solution with the required amount of freshly distilled DMSO. In addition a controlled experiment was carried out by using freshly distilled DMSO solvent alone.

\section{Antibacterial Screening}

Muller-Hinton agar media were used for the antibacterial studies. The dehydrated Muller-Hinton agar (38gm) was dissolved in $1000 \mathrm{~mL}$ distilled water. The pure culture of the bacterial strains Staphylococcus aureus, Escherichia coli, Bacillus subtilis and Salmonella typhi was sub cultured by inoculating in the nutrient broth and they were incubated at $37^{\circ} \mathrm{C}$ for $18 \mathrm{hrs}$. The agar plates were prepared by using the above Muller-Hinton agar media, and wells were dug with the help of $6 \mathrm{~mm}$ sterile metallic cork bore. Each plate was inoculated with 18 hrs old bacterial culture using a micropipette and spreaded regularly using bent glass rod on each plate. The drug Gentamycin is used as per standard. Different concentrations of the test compounds was incorporated into the wells using micropipette and the plates were kept for incubation period, the diameter of the inhibition zone generate by each test compound against bacterial growth was measured using anti biogram zone measuring scale.

\section{Antifungal screening}

Potato dextrose agar (PDA) media was used for the antifungal studies. The following ingredients were used prepare the media: potatoes (sliced washed unpeeled) $200 \mathrm{~g}$, dextrose $20 \mathrm{~g}$, and agar $20 \mathrm{~g}$ in $1000 \mathrm{~mL}$ distilled water. The pure cultures Cladosporium oxysporum, Candida albicans, and Aspergillus Niger were inoculated on PDA slants. These slants were incubated at $32^{\circ} \mathrm{C}$ for 7 days. To these 7 days old slants of fungal strains, $10 \mathrm{~mL}$ of $0.1 \%$ tween- 80 solution were added, and the culture were scraped with sterilized inoculating loop to get uniform spore suspension. The agar plates were prepared through using the above Potato dextrose agar media and wells were dug with the help of $6 \mathrm{~mm}$ sterile metallic cork bore. Each plate was inoculated with 7 days old spore suspension of each fungal culture using a micropipette and spreaded regularly using bent glass rod on each plate. Next each well was incorporated with the test compound solution of different concentrations. The drug Flucanozole is used as standard. All the inoculated plates were incubated at $32^{\circ} \mathrm{C}$ for 48 hrs. Soon after the completion of incubation period the diameter of the inhibition zone generated by each test compound against fungal growth is measured using antibiogram zone measuring scale.

\section{DNA cleavage Experiment}

To extent to which the newly synthesized ligands and metal complexes could function as DNA cleavage agents they were examined using plasmid pBR322 DNA (Merck Genei, Bengaluru, Cat. No.105850) as target molecule according to the literature method. ${ }^{29}$ The cleavage activity of the test compounds was analyzed by agarose gel electrophoresis method. The $600 \mathrm{mg}$ of agarose was dissolved in $60 \mathrm{~mL}$ of TAE buffer $(4.84 \mathrm{~g}$ Tris base, pH 8.0, 0.5 M EDTA) by boiling. When the gel attains approximately $55^{\circ} \mathrm{C}$, it was poured into the gel cassette fitted with comb. The gel was allowed to solidify and then carefully the combs were removed. The gel was placed in the electrophoresis chamber flooded with TAE buffer. A test compound was prepared in DMSO $\left(1 \mathrm{mg} \mathrm{mL} \mathrm{mL}^{-1}\right)$. The test compounds were added separately to the isolated plasmid pBR322 DNA (225 mg) and incubated for $2 \mathrm{hrs}$ at $37^{\circ} \mathrm{C}$. After the incubation period, the $20 \mu \mathrm{L}$ of DNA sample (mixed with bromophenol blue dye at 1: 1 ratio) is loaded carefully into the electrophoresis chamber wells along with standard DNA marker and a constant electricity of $50 \mathrm{~V}$ passed for about $30 \mathrm{~min}$. The gel was removed carefully and stained with Ethidium bromide (EtBr) solution $(10 \mu \mathrm{g} /$ $\mathrm{mL}$ ) for 10-15 min. The bands were observed under UV transilluminator (UVP, Germany) and photographed to determine an extent of DNA cleavage, and the results were compared with those of a standard DNA marker.

\section{In vitro cytotoxicity}

The brine shrimp lethality biological assay has been chosen to evaluate the in vitro cytotoxicity effect of the newly synthesized Schiff base ligand and its metal complexes by using the protocol of Meyer et.al. ${ }^{30}$ This is an efficient, rapid, inexpensive test and has been good correlation with cytotoxic activity. Brine shrimp (Artemia salina) eggs was hatch in a shallow rectangular plastic dish $(22 \times 32 \mathrm{~cm})$ filled with artificial seawater, which was prepared with a mixture of commercial salt and double distilled water. An unequal partition was made in the plastic dish with the help of a perforated apparatus. Approximately $50 \mathrm{mg}$ of eggs are sprinkled into 
the large compartment, which has darkened while the minor compartments were open to ordinary light. Two days after nauplii were collected by pipette by lighted side. Samples of the test compound were prepared by dissolving $20 \mathrm{mg}$ of each compound in $2 \mathrm{ml}$ of DMSO. From this stock solution 100, 50 and $25 \mu \mathrm{g} \mathrm{mL}^{-1}$ was transferred to nine vials (three for each dilution were used for each test sample and $\mathrm{LD}_{50}$ is the mean of three values and one vial were kept as control having $2 \mathrm{~mL}$ DMSO only. The solvent were allowed to evaporate overnight. After two days, when shrimp larvae was ready, $1 \mathrm{~mL}$ of seawater and 10 shrimps was added to each vial (30 shrimp/dilution) and the volume was adjusted with seawater to $10 \mathrm{~mL}$ per vial. After $24 \mathrm{hrs}$ the number of survivors was counted. Data is analyzed by a Finney computer program to determine the $\mathrm{LD}_{50}$ values. $^{31}$

\section{RESULTS AND DISCUSSION}

\section{Chemistry}

In our study, a new Schiff base based thiazole derivative has been synthesized by condensation of 2-amino4-phenyl thiazole and 3-aldehydosalicylic acid in the presence of catalytic amount of glacial acetic acid with good yield of $80 \%$ as shown in Scheme-1. The purity of the current Schiff base ligand was checked by running TLC on a silica gel coated plate using CyclohexaneEthyl acetate (80:20\%) as the eluent. The complexes were synthesized by the reaction of thiazole ligand with metal chloride in 1:1 $\mathrm{M}$ ratio in ethanol Schemes-2. The ligands and their complexes were found to be stable at room temperature and soluble in in DMSO and DMF. Molar conductance data of the metal complex was measured in DMF at $10^{-3} \mathrm{M}$ and all the complexes showed conductance in the range of $40-62 \mathrm{ohm}^{-1} \mathrm{~cm}^{2} \mathrm{~mol}^{-1}$ at ambient temperature indicating non-electrolytic in nature ${ }^{24}$ and outside their coordination sphere there is no counter ion present. The thermal nature of the complexes has been obtained by TGA/DTA analysis. The analytical and physical data of thiazole ligand and their metal complexes are presented in Table 1. The formation of thiazole ligands frameworks and bidentate $\mathrm{O}-\mathrm{O}$ donar nature of the Schiff base with metals for the formation of complexes were obtained from characteristic band positions in FT IR and resonance signals in ${ }^{1} \mathrm{H}$ NMR, Mass spectra and elemental analysis. These data of the metal complexes suggest that metal to ligand ratio of the metal complexes 1:1 stoichiometry of the type $\left[(\mathrm{M})(\mathrm{L})(\mathrm{Cl})_{2}\right]$ where $\mathrm{M}$ is metal and $\mathrm{L}$ is ligand as shown in Scheme-2.

\section{IR spectral studies}

The identification for the formation of thiazole Schiff base were obtained from the absence of IR characteristic band for amino group attached to thaizole ring and the carbonyl group of aldehyde. The IR spectrum of the Schiff base ligand clearly indicates sharp band at 1697 $\mathrm{cm}^{-1}$ is due to presence of carbonyl group $(\mathrm{C}=\mathrm{O})$ of acid and displayed one sharp band at $1629 \mathrm{~cm}^{-1}$ is due to $\mathrm{C}=\mathrm{N}$ of azomethine group of Schiff base. Two broad bands observed at $3152 \mathrm{~cm}^{-1}$ and $3326 \mathrm{~cm}^{-1}$ is attributed to the presence of phenolic-OH group and carboxylic -OH group in Schiff base compound respectively Figure 1. To study the binding mode of Schiff base to the central metal ion in the complex. IR spectrum of the metal complexes the disappearances of phenolic -OH group and carboxylic -OH stretching frequency was observed. This indicates that phenolic $-\mathrm{OH}$ and carboxylic -OH coordinates to the central metal ion. In all metal complexes the phenolic $-\mathrm{OH}$ and carboxylic $-\mathrm{OH}$ group stretching frequency disappeared at $3160 \mathrm{~cm}^{-1}$ and $3320 \mathrm{~cm}^{-1}$ region, this indicates that phenolic oxygen and carboxylic directly coordinating with metalions ${ }^{25}$ Figure 2. The complexation of meal ion with ligand were further confirmed by the appearance of new weak intensity, non ligand bands in the region appears at 534 to $582 \mathrm{~cm}^{-1}$ due to presence of metal oxygen band (M-O) and another bond forms at region $354-379 \mathrm{~cm}^{-1}$ due to $\mathrm{M}-\mathrm{Cl}$ bond Figure 3. The IR data of Ligand and its metal complexes were presented in Table 2.

\section{${ }^{1} \mathrm{H}$ NMR spectrum}

The ${ }^{1} \mathrm{H}$ NMR data of Schiff base and its Zn (II) complex are presented in Table 3 . The proton spectrum of Schiff base display $8.0 \mathrm{ppm}$ appears as singlet due to the presence of $\mathrm{CH}=\mathrm{N}$ and 8 aromatic protons appears as multiplates in the region between 7.25 to $7.40 \mathrm{ppm}$. Carboxylic acid proton appears as singlet $12.80 \mathrm{ppm}(\mathrm{s}, 1 \mathrm{H}$ $\mathrm{COOH})$ and a phenolic proton appears at $7.14 \mathrm{ppm}(\mathrm{s}$, $1 \mathrm{H} \mathrm{OH})$. The ${ }^{1} \mathrm{H}$ NMR of zinc (II) complex displayed all aromatic protons as multiplates in region 7.30 to 8.09 (m, 8H Ar-H). ${ }^{1} \mathrm{H}$ NMR spectral data of Schiff base ligand and its zinc (II) complexes confirms the formation of $\mathrm{Zn}$-complexes with ligand. One phenolic -OH proton and carboxylic -OH disappearance is observed in the $\mathrm{Zn}$ complex ${ }^{1} \mathrm{H}$ NMR spectra. Accordingly Figure 4 and 5 this clearly confirms about phenolic oxygen coordinate with metal ion in the complex.

\section{Mass Analysis}

The ESI mass spectra of Schiff base ligand and its Co (II) and $\mathrm{Ni}$ (II) complexes are performed to determine their molecular weight and study their fragmentation. The mass spectrum of ligand showed a peak recorded 
at $\mathrm{m} / \mathrm{z} 324$ due to $\mathrm{M}^{+1}$ corresponding to the molecular weight of the ligand. Further, this molecular ion underwent fragmentation peak recorded at $\mathrm{m} / \mathrm{z} 137$ (38 $\%$ ) followed by expulsion of $\mathrm{C}_{7} \mathrm{H}_{5} \mathrm{O}_{3}$ molecule gave a fragment ion peak. The fragmentation of ligand may represent the $\mathrm{C}_{3} \mathrm{HN}_{2} \mathrm{~S}$ gives at $\mathrm{m} / \mathrm{z} 96.99(12 \%)$ value and remaining fragmentations are in agreement with the molecular formula Figure 6. The ESI mass spectrum of Co (II) complex shown a peak due to $\mathrm{M}^{+1}$ at 450 $\mathrm{m} / \mathrm{z}$. this molecular ion underwent fragmentation at 292 and 162 loss of $\mathrm{C}_{8} \mathrm{H}_{4} \mathrm{Cl}_{2} \mathrm{CoNO}_{3}$ and $\mathrm{C}_{9} \mathrm{H}_{6} \mathrm{NS}$ respectively. Similarly, ESI mass spectrum of $\mathrm{Ni}$ (II) complex shows a peak due to $\mathrm{M}^{+1}$ at $449.9 \mathrm{~m} / \mathrm{z}$. This molecular underwent fragmentation at 291 and 162 due to loss of $\mathrm{C}_{8} \mathrm{H}_{4} \mathrm{Cl}_{2} \mathrm{NNiO}_{3}$ and $\mathrm{C}_{9} \mathrm{H}_{6} \mathrm{NS}$ respectively Figure 7 .

\section{Thermal studies}

In the present investigation, heating rates were suitably controlled at $20^{\circ} \mathrm{C} \mathrm{min}{ }^{-1}$ under inert atmosphere the weight loss was measured from the ambident temperature up to loss $700^{\circ} \mathrm{C}$. The results of the TGA of the metal complexes show that the metal complexes lost their lattice water in the rage show $100-180^{\circ} \mathrm{C}$. The presence water molecule in the lattice suggested by IR spectra is also confirmed by TGA. TGA and TDA curves $\mathrm{Cu}$ (II) complexes showed that the complex is stable up to $230^{\circ} \mathrm{C}$ and no weight loss is observed before this temperature. The first degradation occurred at $231.88^{\circ} \mathrm{C}$, with the loss of the two chlorine atoms. The organic moiety decomposed further with increasing temperature. Although the decomposed fragments of ligand could not approximated owing to continuous weight loss as indicated by horizontal plateau on the

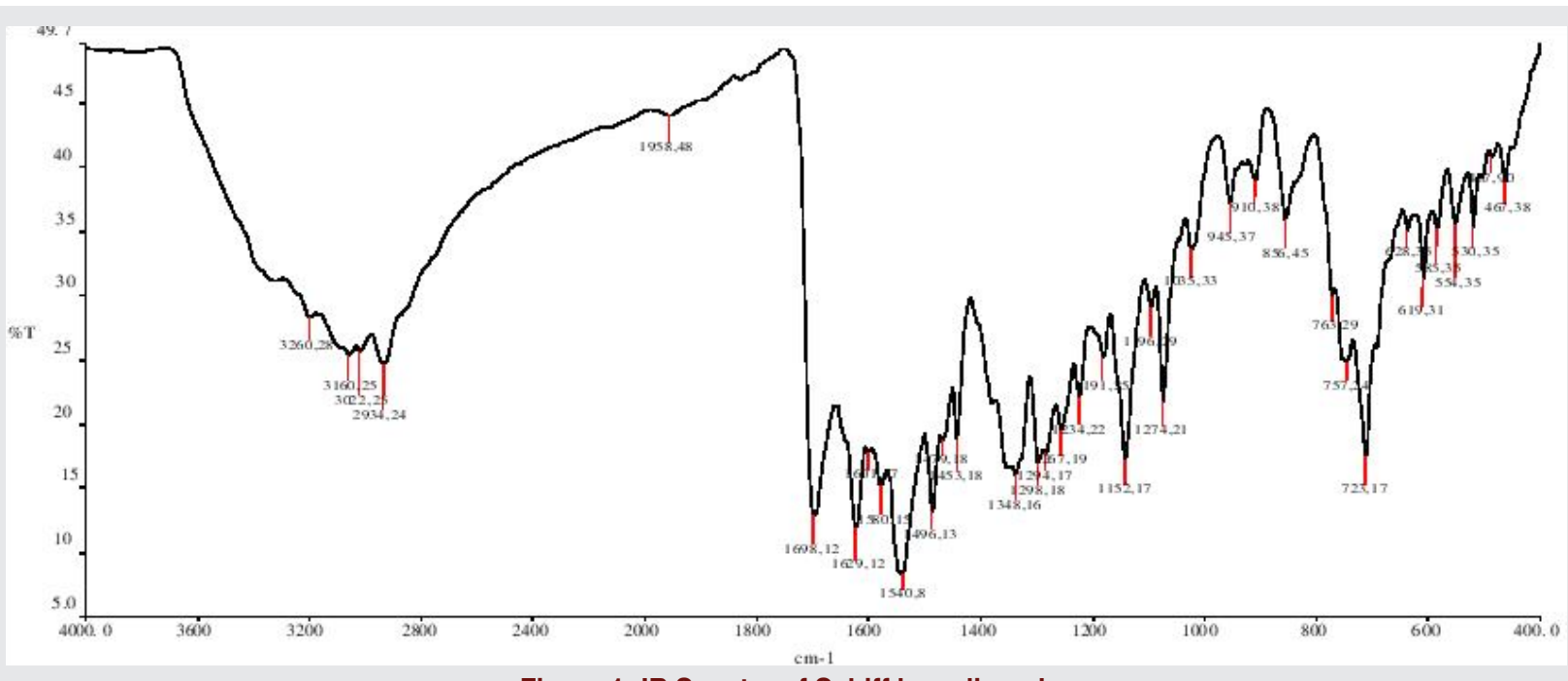

Figure 1: IR Spectra of Schiff base ligand.

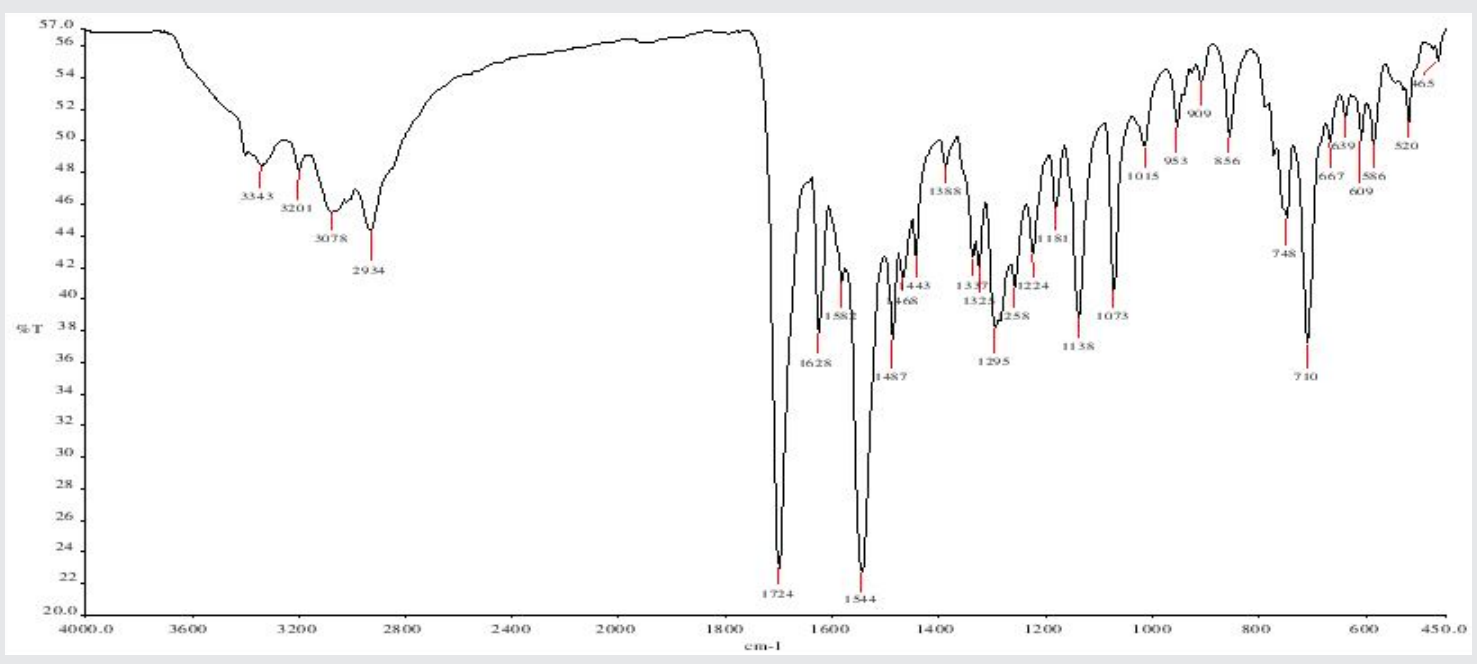

Figure 2: IR Spectra of metal complex Cu (II). 
TG curves for $\mathrm{Cu}$ complex. The complete decomposition of ligand occurred at $\approx 620^{\circ} \mathrm{C}$ for $\mathrm{Cu}$ complex. At the end final step i.e. $550^{\circ} \mathrm{C}-700^{\circ} \mathrm{C}$ stable metallic oxides were found. ${ }^{26}$ The decomposition of complexes as higher than ligand indicates that the thermal stability of the complexes is increased due to the ligand coordinated with metal ion to form ring.

\section{Antimicrobial Results}

\section{In vitro Antimicrobial Activity}

The In-vitro antimicrobial activity of all newly synthesized compounds were screened against E.coli,
S.aureus, B.subtilis and S.typi bacteria and C.albicans, C.oxysporum, and A.niger fungal strains by minimum inhibitory concentration (MIC) method. The MIC profile of the entire compound against bacteria and fungi are summarized in Table 4. A comparative study of the ligand and their metal complexes indicates that complexes exhibit higher antimicrobial activity than free ligand and this activity enhanced on coordination with metal ions. This enhancement in the activity may be rationalized on the basis that ligands mainly posses $\mathrm{C}=\mathrm{N}$ bond. The enhanced activity of the complexes over the ligand can be explained on the basis of chelation theory. ${ }^{27,28}$ It is observed that in complex, the posi-

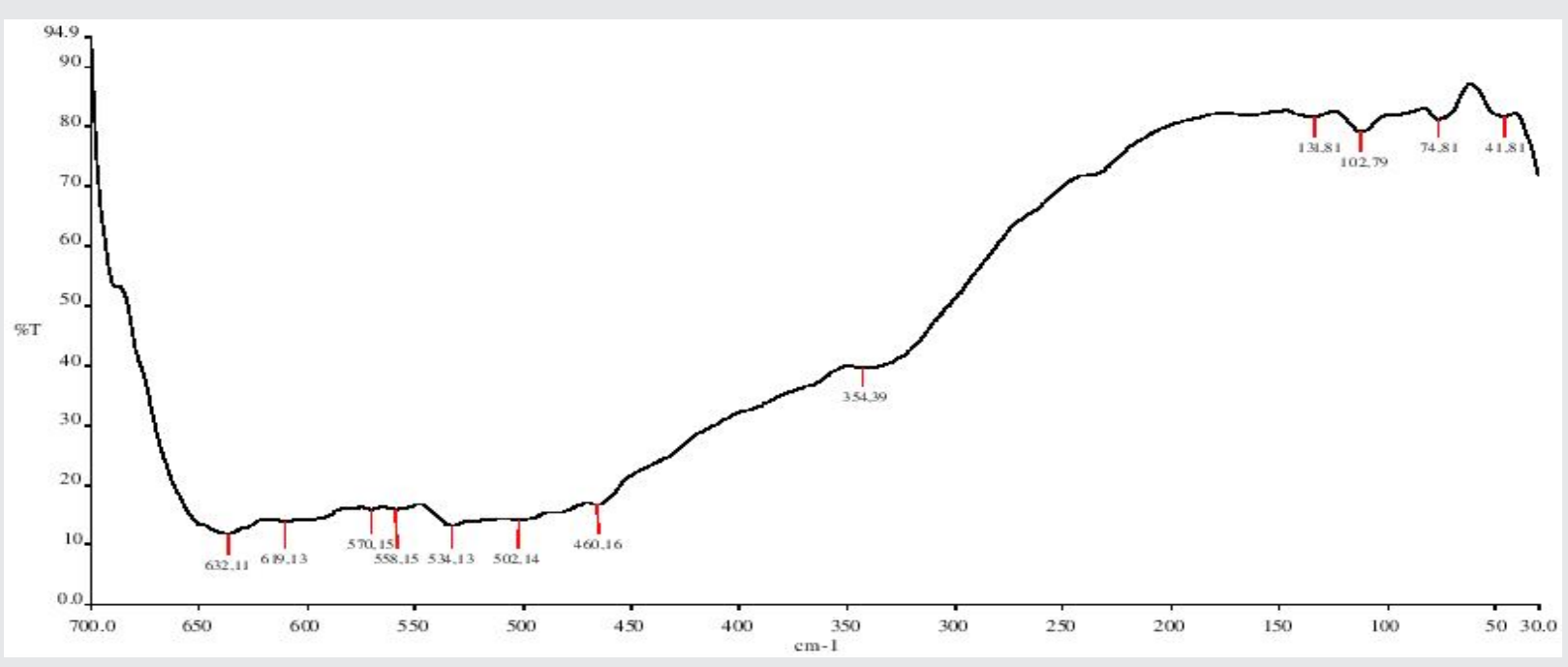

Figure 3: FAR- IR Spectra of metal complex Cu (II).
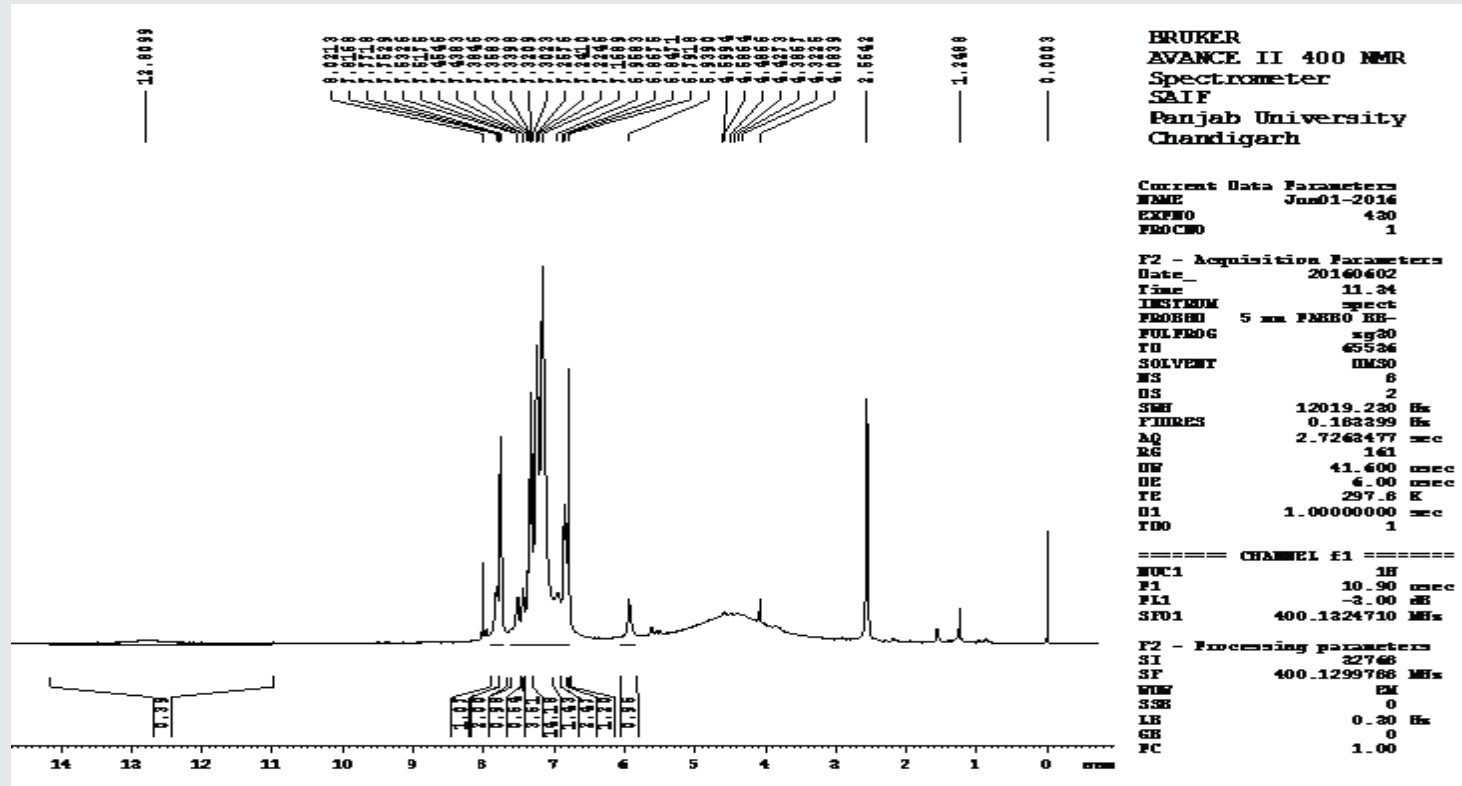

Figure 4: ${ }^{1} \mathrm{H}$ NMR of Schiff base ligand. 
tive charge of the metal is moderately mutual with the donor atoms present in the ligand and there may be $\pi$-electron delocalization over the whole chelating. This increases the lipophilic character of the metal chelates and favors its permeation through the lipoid layer of the bacterial membranes and also other factors which increase the activity, namely solubility, conductivity, and bond length between the metal and the ligand.

\section{DNA Cleavage Activity}

The interaction of plasmid pBR322 DNA with newly synthesized ligand and its metal complexes was stud- ied using agarose gel electrophoresis method. The gel picture showing cleavage of plasmid pBR322 DNA is shown in Figure 8. The characterization of DNA recognition by transition metal complexes has been aided by the DNA cleavage chemistry associated with redoxactive or photo activated metal complexes. The electrophoresis analysis clearly revealed that the ligand and its metal complexes acted on DNA because of a difference in molecular weight between the control and treated DNA samples. The differences were observed in the bands of lanes of complexes compared with the control

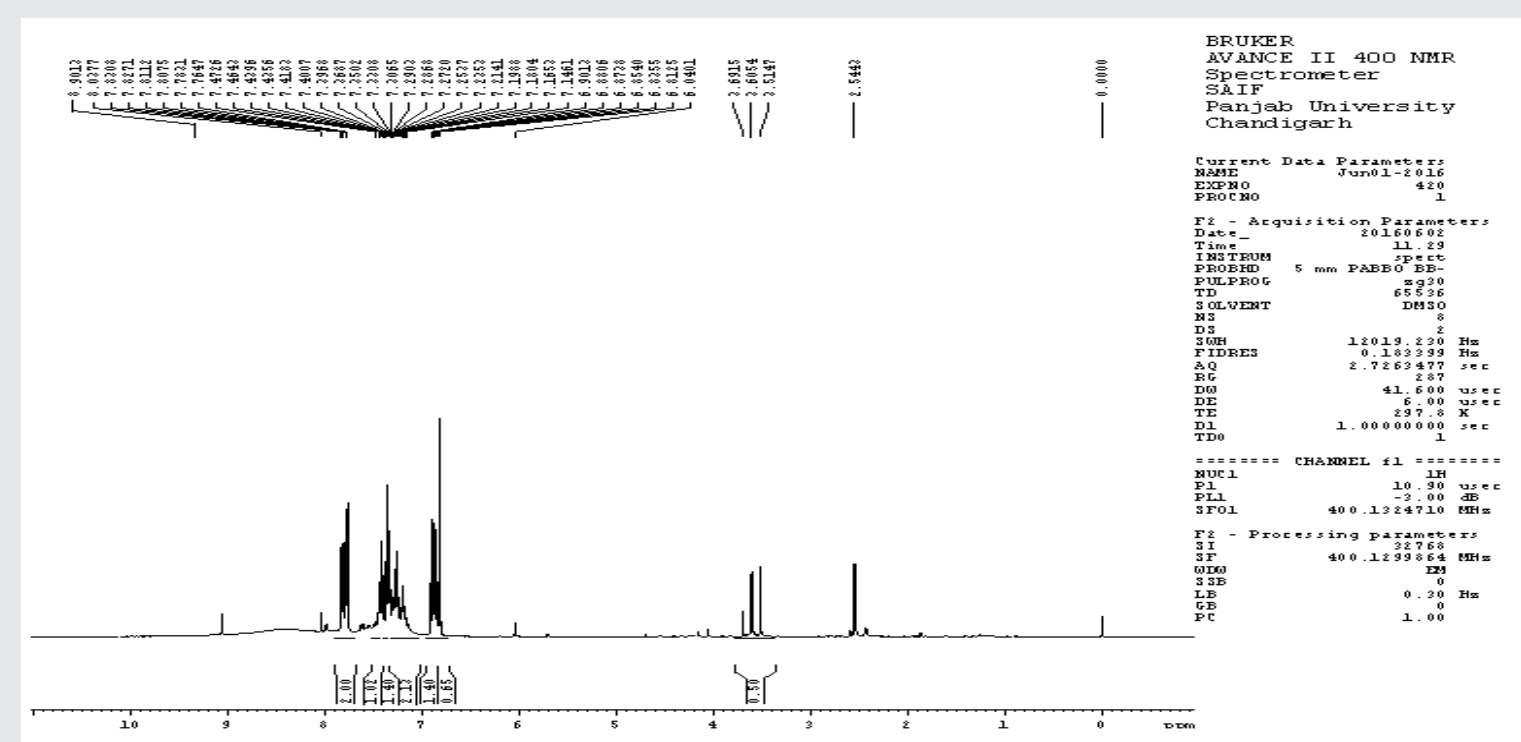

Figure 5: ${ }^{1} \mathrm{H}$ NMR of metal complex $\mathrm{Zn}$ (II).

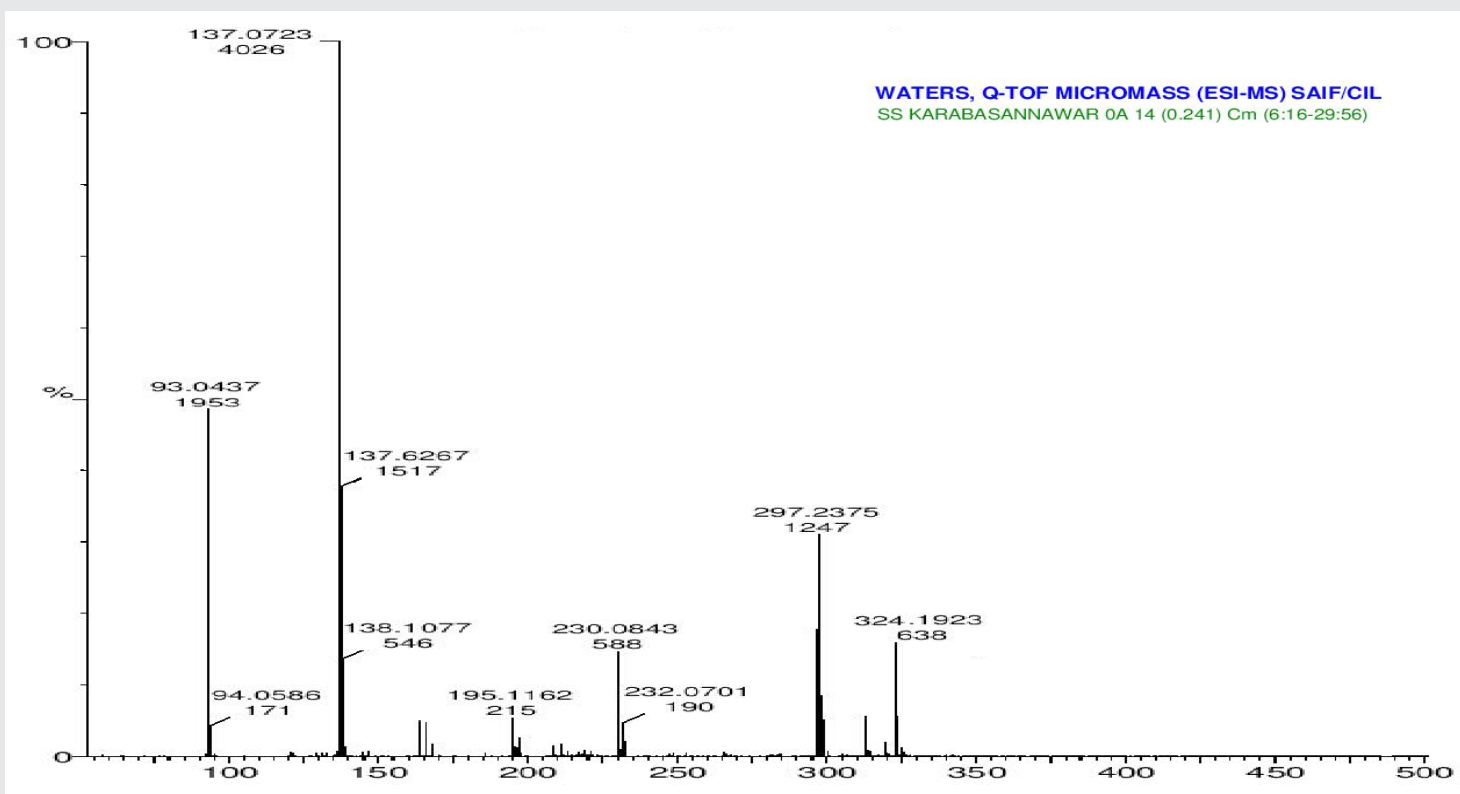

Figure 6: Mass spectrum of the Schiff base. 


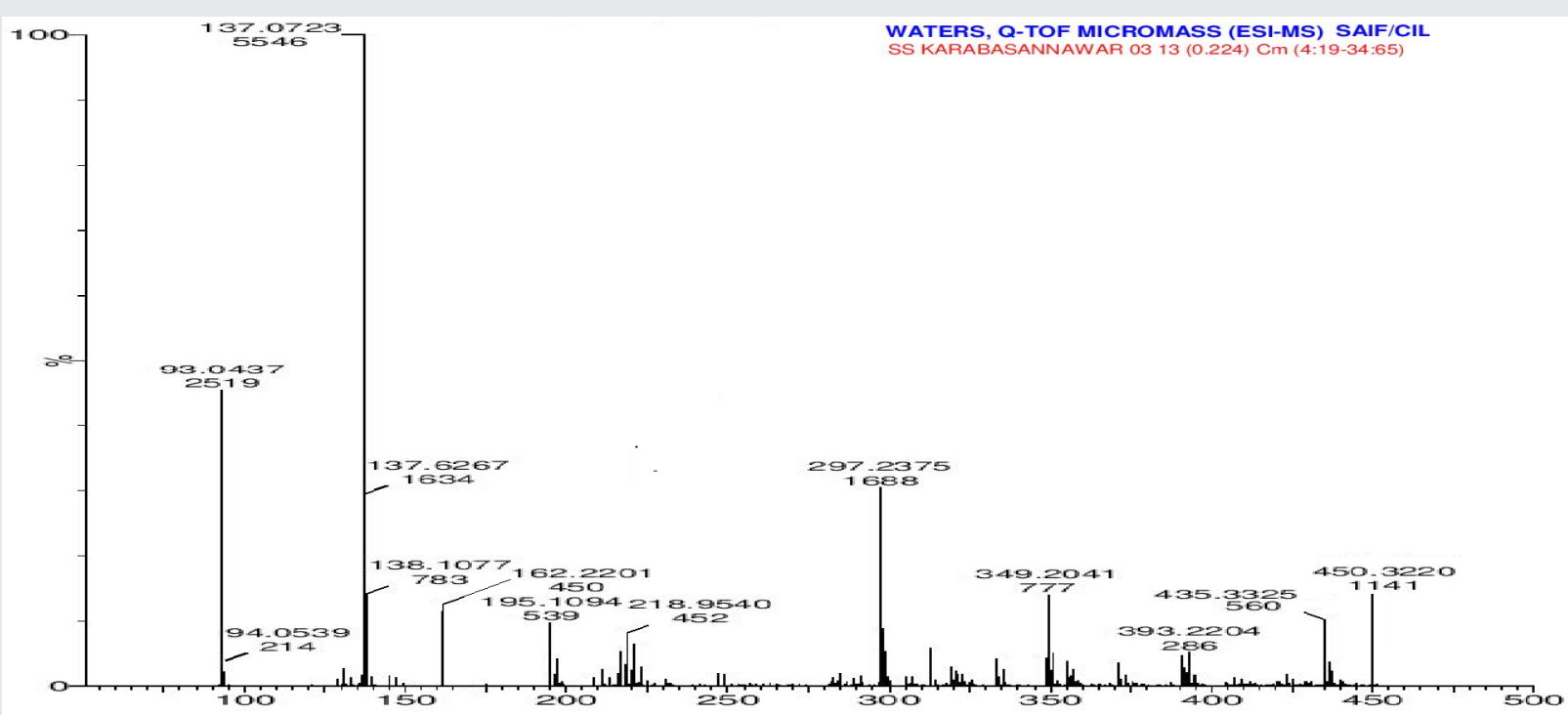

Figure 7: Mass spectrum of the metal complex Co (II).

Table 1: Physical, Analytical and Molar Conductance data of Ligand and its complexes

\begin{tabular}{|c|c|c|c|c|c|c|c|c|c|c|}
\hline Compounds & Molecular formula & $\begin{array}{c}\text { Mol. } \\
\text { Wt }\end{array}$ & M.P & \multicolumn{5}{|c|}{ Elemental analysis [\%] (calc.) } & \multirow[t]{2}{*}{$\begin{array}{c}\text { Molar } \\
\text { Conductance }\end{array}$} & \multirow[t]{2}{*}{ Color } \\
\hline & & & & M & C & $\mathrm{H}$ & $\mathrm{N}$ & $\mathrm{Cl}$ & & \\
\hline Schiff base & $\mathrm{C}_{17} \mathrm{H}_{12} \mathrm{~N}_{2} \mathrm{O}_{3} \mathrm{~S}$ & 324 & $180-190^{\circ} \mathrm{C}$ & - & $\begin{array}{c}63.20 \\
(63.15)\end{array}$ & $\begin{array}{c}3.36 \\
(3.73)\end{array}$ & $\begin{array}{c}8.57 \\
(8.60)\end{array}$ & - & - & Brown \\
\hline Cu complex & {$\left[\mathrm{Cu}\left(\mathrm{C}_{17} \mathrm{H}_{10} \mathrm{~N}_{2} \mathrm{O}_{3} \mathrm{~S}\right) \mathrm{Cl}_{2}\right]$} & 454.9 & $>250^{\circ} \mathrm{C}$ & $\begin{array}{c}13.72 \\
(13.89)\end{array}$ & $\begin{array}{c}44.53 \\
(44.59)\end{array}$ & $\begin{array}{c}2.35 \\
(2.40)\end{array}$ & $\begin{array}{c}6.23 \\
(6.14)\end{array}$ & $\begin{array}{c}15.49 \\
(15.52)\end{array}$ & 50 & Green \\
\hline Zn complex & {$\left[\mathrm{Zn}\left(\mathrm{C}_{17} \mathrm{H}_{10} \mathrm{~N}_{2} \mathrm{O}_{3} \mathrm{~S}\right) \mathrm{Cl}_{2}\right]$} & 458.6 & $>262^{\circ} \mathrm{C}$ & $\begin{array}{c}14.18 \\
(14.26)\end{array}$ & $\begin{array}{c}44.82 \\
(44.41)\end{array}$ & $\begin{array}{c}2.23 \\
(2.39)\end{array}$ & $\begin{array}{c}5.59 \\
(6.11)\end{array}$ & $\begin{array}{c}15.43 \\
(15.46)\end{array}$ & 48 & Grey \\
\hline Ni complex & {$\left[\mathrm{Ni}\left(\mathrm{C}_{17} \mathrm{H}_{10} \mathrm{~N}_{2} \mathrm{O}_{3} \mathrm{~S}\right) \mathrm{Cl}_{2}\right]$} & 459.9 & $>258^{\circ} \mathrm{C}$ & $\begin{array}{c}6.10 \\
(6.21)\end{array}$ & $\begin{array}{c}44.19 \\
(45.18)\end{array}$ & $\begin{array}{c}2.13 \\
(2.23)\end{array}$ & $\begin{array}{c}5.09 \\
(6.20)\end{array}$ & $\begin{array}{c}15.39 \\
(15.69)\end{array}$ & 56 & Grey \\
\hline Co complex & {$\left[\mathrm{Co}\left(\mathrm{C}_{17} \mathrm{H}_{10} \mathrm{~N}_{2} \mathrm{O}_{3} \mathrm{~S}\right) \mathrm{Cl}_{2}\right]$} & 452.1 & $>254^{\circ} \mathrm{C}$ & $\begin{array}{c}12.90 \\
(13.03)\end{array}$ & $\begin{array}{c}45.06 \\
(45.16)\end{array}$ & $\begin{array}{c}2.03 \\
(2.13)\end{array}$ & $\begin{array}{c}5.19 \\
(6.20)\end{array}$ & $\begin{array}{c}15.78 \\
(15.68)\end{array}$ & 60 & Blue \\
\hline Cd complex & {$\left[\mathrm{Cd}\left(\mathrm{C}_{17} \mathrm{H}_{10} \mathrm{~N}_{2} \mathrm{O}_{3} \mathrm{~S}\right) \mathrm{Cl}_{2}\right]$} & 505.6 & $>256^{\circ} \mathrm{C}$ & $\begin{array}{c}22.09 \\
(22.23)\end{array}$ & $\begin{array}{c}44.07 \\
(45.16)\end{array}$ & $\begin{array}{c}2.09 \\
(1.99)\end{array}$ & $\begin{array}{c}6.02 \\
(5.54)\end{array}$ & $\begin{array}{c}15.07 \\
(14.02)\end{array}$ & 55 & Purple \\
\hline
\end{tabular}

\begin{tabular}{|c|c|c|c|c|c|c|}
\hline \multicolumn{7}{|c|}{ Table 2: The IR data of Ligand and its metal complexes $\left(\mathbf{c m}^{-1}\right)$} \\
\hline Compounds & C=O & C=N & Phenolic - OH & Carboxylic - OH & M-Cl & M-O \\
\hline Schiff base & 1697 & 1629 & 3160 & 3260 & -- & -- \\
\hline Cu complex & 1724 & 1628 & --- & --- & 534 & 368 \\
\hline Co complex & 1708 & 1628 & --- & -- & 562 & 354 \\
\hline Ni complex & 1719 & 1621 & --- & --- & 538 & 359 \\
\hline Zn complex & 1721 & 1626 & --- & --- & 382 & 379 \\
\hline Cd complex & 1716 & 1624 & --- & 546 & 362 \\
\hline
\end{tabular}

\begin{tabular}{|c|c|}
\hline \multicolumn{2}{|c|}{ Table 3: The ${ }^{~}{ }^{\mathrm{H}}$ NMR data of ligand and its Zn (II) complex } \\
\hline Ligand/complex & ${ }^{1} \mathrm{H}$ NMR ppm \\
\hline Ligand & $8.0(\mathrm{~s}, 1 \mathrm{H} \mathrm{CH}=\mathrm{N}), 7.25$ to $7.40(\mathrm{~m}, 8 \mathrm{H}, \mathrm{Ar}-\mathrm{H}), 7.14(\mathrm{~s}, 1 \mathrm{H} \mathrm{OH}), 8.90(\mathrm{~s}, 1 \mathrm{H} \mathrm{COOH})$, \\
\hline Zn complex & $8.15(\mathrm{~s}, 1 \mathrm{H} \mathrm{CH}=\mathrm{N}), 7.30$ to $7.45(\mathrm{~m}, 8 \mathrm{H}, \mathrm{Ar}-\mathrm{H})$, \\
\hline
\end{tabular}




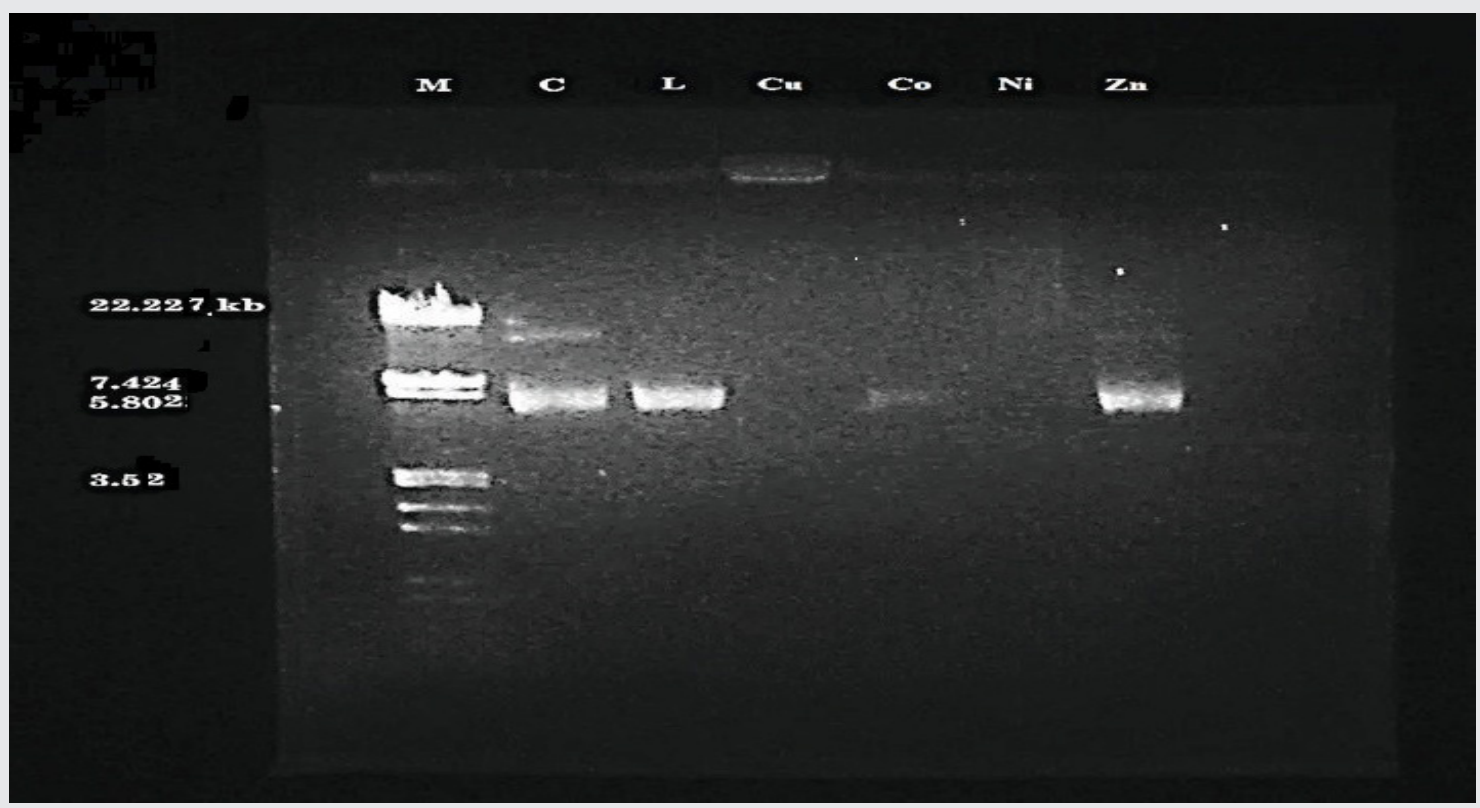

Figure 8: 8:DNA cleavage on plasmid pBR 322: M: standard DNA, C: control DNA, L: Schiff base ligand, Cu: $\mathrm{Cu}$ (II) complex, Co: Co(II) complex, Ni: Ni(II) complex and $\mathrm{Zn}$ : Zn(II) complex.

\begin{tabular}{|c|c|c|c|c|c|c|c|}
\hline \multirow{3}{*}{ Compounds } & \multicolumn{7}{|c|}{ MIC Value in $\mu \mathrm{g} \mathrm{mL}^{-1}$} \\
\hline & \multicolumn{4}{|c|}{ Bacteria } & \multicolumn{3}{|c|}{ Fungi } \\
\hline & E.coli & S.aureus & B.subtilis & S.typhi & C.albicans & C.oxysporum & A.niger \\
\hline Schiff base & 50 & 76 & 50 & 100 & 75 & 51 & 50 \\
\hline Cu complex & 13 & 25 & 25 & 50 & 25 & 13 & 13 \\
\hline Co complex & 25 & 50 & 13 & 50 & 13 & 13 & 25 \\
\hline Ni complex & 13 & 25 & 25 & 50 & 25 & 13 & 25 \\
\hline Zn complex & 25 & 50 & 25 & 75 & 50 & 25 & 25 \\
\hline Cd complex & 13 & 13 & 13 & 25 & 13 & 25 & 13 \\
\hline Gentamycin & 13 & 13 & 13 & 13 & - & - & - \\
\hline Fluconazole & - & - & -- & & 13 & 13 & 13 \\
\hline
\end{tabular}

DNA of pBR322 due to the relaxation of circular DNA into linear form and this shows that the control DNA alone does not show any apparent cleavage, whereas the ligand and its metal complexes do show. In the current investigation, the Ethidium bromide (EtBr) stained banding pattern of plasmid pBR322 DNA were tested with newly synthesized ligand and its metal complexes. In the present case, the ligand and its $\mathrm{Cu}$ (II), Co (II) and $\mathrm{Zn}$ (II) complexes showed complete cleavage of super coiled DNA and the Ni (II) and Cd (II) complex showed incomplete cleavage of relaxed DNA and complete cleavage of super coiled DNA. This clearly revels the important role of coordination of $\mathrm{O}-\mathrm{O}$ groups to the metal ion in these DNA cleavage activities. On the basis these information's, it has been concluded that all the newly synthesized compounds under present study are good pathogenic microorganisms inhibitor; as evident on the DNA cleavage of pBR322.

\section{In vitro cytotoxicity}

All the synthesized compounds was screened for their cytotoxicity (brine shrimp bioassay) using the protocol of Mayer et al. ${ }^{30}$ From the data recorded in table it is evident that all newly synthesized metal complexes exhibited potent activity when compared to the free ligand. The $\mathrm{Cu}$ (II) and Ni (II) complexes displayed significant potent activity as LD50 $=1.169 \times 10^{-4}$ and $1.174 \times 10^{-4}$ $\mathrm{M} / \mathrm{mL}$ respectively against Artemia salina. The In vitro cytotoxicity results are summarized in Table 5 . 
Table 5: Brine shrimp bioassay data of the Schiff base (L) and its metal complexes

\begin{tabular}{|c|c|}
\hline Compound & LD 50(M/mL) \\
\hline Ligand & $2.5470 \times 10^{-4}$ \\
\hline Cu-complex & $1.169 \times 10^{-4}$ \\
\hline Co-complex & $1.287 \times 10^{-4}$ \\
\hline Ni-complex & $1.174 \times 10^{-4}$ \\
\hline Cd-complex & $1.316 \times 10^{-4}$ \\
\hline Zn-complex & $2.309 \times 10^{-4}$ \\
\hline
\end{tabular}

\section{CONCLUSION}

The newly synthesized Schiff base ligand 3-((4-phenylthiazol-2-ylimino) methyl)-2-hydroxybenzoic behaves as bidentate $\mathrm{O}-\mathrm{O}$ donor and the complexes of square planar type $\left[\mathrm{ML}(\mathrm{Cl})_{2}\right]$. The help of various physicochemical and spectroscopic methods such as IR, ${ }^{1} \mathrm{H}$ $\mathrm{NMR}$, the square planar geometries of $\mathrm{Cu}(\mathrm{II}), \mathrm{Co}(\mathrm{II})$, $\mathrm{Ni}(\mathrm{II}), \mathrm{Cd}(\mathrm{II})$ ad $\mathrm{Zn}$ (II) complexes have been proposed scheme 2. The newly synthesized metal complexes having good antimicrobial activity when compared to Schiff base ligand. The DNA cleavage activity of all the newly synthesized compounds showed the cleavage of plasmid DNA pBR 322 and cytotoxicities of $\mathrm{Cu}$ (II) and $\mathrm{Ni}$ (II) complexes indicate potent cytotoxic agents that might become potent anticancer agent in clinical trials.

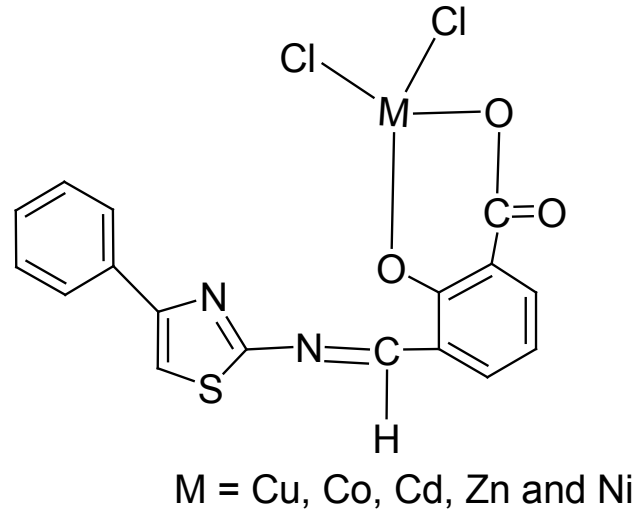

Scheme 2: Proposed Structure of the complex

\section{ACKNOWLEDGMENT}

Authors are thankful to Principal, HOD Department of chemistry BLDE's science college Jamkhandi, Karnataka, INDIA for providing necessary facilities for research. Authors are extended their thanks to professor, chairman of department chemistry and Coordinator of Research and development centre Bharathiar University Coimbatore. Authors are also thanks to SAIF Punjab University, Chandigarh, for providing FT-IR, ${ }^{1} \mathrm{H}$ NMR and ESI mass spectral data, and STIC Cochin University for providing TGA/TDA data and Biogenic Research and Training Centre in Biotechnology, Hubli, for Biological analysis.

\section{CONFLICT OF INTEREST}

There is no conflict of interest.

\section{ABBREVIATION USED}

FT-IR: Fourier Trans- form Infrared; 1H NMR: Proton Nuclear Magnetic Resonance; ESI mass: Electrospray Ionization Mass Spectrometry; TGA/TDA: Thermo gravimetric analysis/Differential thermal analysis; DNA: Deoxyribonucleic acid; TLC: Thinlayer chromatography; DMSO: Dimethyl sulfoxide; TMS: Tetramethylsilane; DMF: Dimethylformamide; MTCC: Microbial Type Culture Collection and Gene Bank; PDA: Potato dextrose agar; EDTA: Ethylene diamine tetraacetic acid; MIC: Minimum inhibitory concentration; LD $_{50}$ : Lethal Dose; ETBr: Ethidium bromide.

\section{REFERENCES}

1. Abu-Dief AM, Mohamed IMA. A review on versatile applications of transition metal complexes incorporating Schiff bases. Beni-Suef Univ J Basic Appl Sci. 2015;4(2):119-33. http://dx.doi.org/10.1016/j.bjbas.2015.05.004.

2. Abd El-halima HF, Omarb MM, Gehad GM. Synthesis, structural, thermal studies and biological activity of a tridentate Schiff base ligand and their transition metal complexes, Spectrochimica Acta Part A. 2011;78(1):36-44. doi:10.1016/j.saa.2010.06.003. https://doi.org/10.1016/j.saa.2010.06.003.

3. Maria DMC, Silva Rd, Gonçalves JM, Silva ALR, Paula OCFC. Molecular thermochemical study of $\mathrm{Ni}$ (II), $\mathrm{Cu}$ (II) and Zn (II) complexes with N,N'bis (salicylaldehydo) ethylenediamine, Journal of Molecular Catalysis A: Chemical. 2004;224(1):207-12.

4. Singh P, Goel RL, Singh BP. "8-acetyl-7-hydroxy-4-methyl coumarin as a gravimetric reagent for $\mathrm{Cu} 2+$ and Fe3+," Journal of the INDIAn Chemical Society. 1975;52(10):958-9.

5. Nagesh GY, Raj KM, Mruthyunjayaswamy BHM. Synthesis, characterization, thermal study and biological evaluation of $\mathrm{Cu}$ (II), Co (II), Ni (II) and Zn (II) complexes of Schiff base ligand containing thiazole moiety. J Mol Struct. 2015;1079:423-32. http://dx.doi.org/10.1016/j.molstruc.2014.09.013.

6. Shukla S, Srivastava RS, Shrivastava SK, Sodhi A, Kumar P. Synthesis, characterization, in vitro anticancer activity, and docking of Schiff bases of 4-amino-1,2-naphthoquinone. Med Chem Res. 2013;22:1604-17. DOI 10.1007/s00044-012-0150-7. https://doi.org/10.1007/s00044-012-0150-7.

7. Salehi M, Amoozadeh A, Salamatmanesh A, Kubicki M, Dutkiewicz G, Samiee S, et al. Synthesis, characterization, crystal structures, computational studies, and antibacterial activities of two new Schiff bases derived from isophthalaldehyde. J Mol Struct. 2015;1091:81-7. https://doi.org/10.1016/j. molstruc.2015.02.060

8. Zaltariov M-F, Cazacu M, Avadanei M, Shova S, Balan M, Vornicu N, et al. Varganici C-D. Synthesis, characterization and antimicrobial activity of new $\mathrm{Cu}(\mathrm{II})$ and $\mathrm{Zn}(\mathrm{II})$ complexes with Schiff bases derived from trimethylsilylpropylp-aminobenzoate. Polyhedron. 2015;100:121-31. http://dx.doi.org/10.1016/j. poly.2015.07.030.

9. Zayed EM, Zayed MA. Synthesis of novel Schiff's bases of highly potential biological activities and their structure investigation. Spectrochim Acta A Mol Biomol Spectrosc. 2015;143:81-90. http://dx.doi.org/10.1016/j. saa.2015.02.024. 
10. Andersen $O$. Principles and recent developments in chelation treatment of metal intoxication. Chem Rev. 1999;99(9):2683-710. 10.1021/cr980453a ; https://doi.org/10.1021/cr980453a.

11. Konstantinovic SS, Radovanovic BC, Cakic Z, Vasic V. Synthesis and characterization of $\mathrm{Co}$ (II), Ni (II), $\mathrm{Cu}$ (II) and Zn (II) complexes with 3-salicylidenehydrazono-2-indolinone. J Serb Chem Soc. 2003;68:641-7. https://doi.org/10.2298/JSC0309641K.

12. Joseyphus RS, Dhanaraj CJ, Nair MS. Synthesis and characterization of some Schiff base transition metal complexes derived from vanillin and $\mathrm{L}(+)$ alanine. Transition Met Chem. 2006;31(6):699-702. DOI 10.1007/s11243006-0048-7. https://doi.org/10.1007/s11243-006-0048-7.

13. Venugopala KN, Jayashree BS. Synthesis and characterization of carboxamides of 2'-Amino-4'-(6-Bromo-3-Coumarinyl) thiazole for their analgesic and anti-inflammatory activity. Indian J Heterocyclic Chem. 2003;12:307-10.

14. Chen P, Horton LB, Mikulski RL, Deng L, Sundriyal S, Palzkill T, et al. 2-Substituted 4,5-dihydrothiazole-4-carboxylic acids are novel inhibitors of metallo- $\beta$-lactamases. Bioorg Med Chem Lett. 2012;22(19):6229-32. https:// doi.org/10.1016/j.bmcl.2012.08.012; PMid:22921080 PMCid:PMC3463135.

15. Shiv JK, Vipin KG, Pramod KS, Nitin K, Rupesh D, Jitendre KG. Thiazoles: having diverse biological activities. Med Chem Res. 2012;21(8):2123-32. https://doi.org/10.1007/s00044-011-9685-2.

16. Nagesh GY, Mahendra RK, Mruthyunjayaswamy BHM. Synthesis, characterization, thermal study and biological evaluation of $\mathrm{Cu}$ (II), Co (II), Ni (II) and Zn (II) complexes of Schiff base ligand containing thiazole moiety, Journal of Molecular Structure. 2015;1079:423-32. http://dx.doi. org/10.1016/j.molstruc.2014.09.013.

17. Prakash GM, Netaji. NK, Anjana SL, Naina N, Rajendra HP, Synthesis and anti-biofilm activity of thiazole Schiff bases. Med Chem Res. 2014;23(2):7909. https://doi.org/10.1007/s00044-013-0672-7.

18. Basavaraj MK, Shambuling SK, Ramesh SG, Mallikarjun BK. Synthesis, characterization and anti-microbial study of some organometallic complexes of multi-dentate Schiff bases derived from 3-Aldehydosalicylic acid at various pH ranges. Drug Invention today. 2013(5)105-12.

19. Li Y, Xu Y, Qian X, Qu B. Naphthalimide-thiazoles as novel photonucleases: molecular design, synthesis, and evaluation, Tetrahedron Letters. 2004;45(6):1247-51. https://doi.org/10.1016/j.tetlet.2003.11.145.

20. de Souza MVN. Synthesis and biological activity of natural thiazoles: An important class of heterocyclic compounds. J Sulfur Chem. 2005;26(45):429-49. http://dx.doi.org/10.1080/17415990500322792.
21. Li Y, Zheng YY, Ming FW. Synthesis, characterization, DNA binding properties and antioxidant activity of Ln (III) complexes with hesperetin-4-one-(benzoyl) hydrazine. Eur J Med Chem. 2009;44(11):4585-95. DOI 10.1007/s10895010-0635-z ; https://doi.org/10.1007/s10895-010-0635-z.

22. Nicola M, Cristin M, Valentina G, Domenico O, Mauro R, Elisabetta G, et al. Revisiting [Pt Cl2(cis-1,4-DACH)]: An Underestimated Antitumor Drug with Potential Application to the Treatment of Oxaliplatin-Refractory Colorectal Cancer J Med Chem. 2012;55(16):7182-92. http://dx.doi.org/10.1021/ jm3006838.

23. Olga N, Jana K, Vendula B, Ctirad H, Marie V, Haimei C, et al. Conformation of DNA modified by monofunctional Ru (II) arene complexes: Recognition by DNA binding proteins and repair. Relationship to cytotoxicity. Chem Biol. 2005;12(1):121-9. DOI 10.1016/j.chembiol.2004.11.008. https://doi. org/10.1016/j.chembiol.2004.11.008.

24. Geary WJ, Coord. Chem Rev. 1971;7(1):81-122. https://doi.org/10.1016/ S0010-8545(00)80009-0.

25. Vinod KG, Ashok KS, Lokesh KK. Thaizole Schiff base turn - on fluorescent chemo sensor for Al+3 ion, Sensors and Actuators B. 2014;195:98-108. http://dx.doi.org/10.1016/j.snb.2013.12.092.

26. Wendlandt WW. Thermal Method of Analysis, Interscience, New York, 1964.

27. Amith KS, Sulekh C. Complexation of Nitrogen and Sulphur donor Schiff 's Base Ligand to $\mathrm{Cr}$ (III) and Ni (II) metal ions: Synthesis, Spectroscopic and Antipathogenic Studies, Spectrochimica Acta A. 2011;78(1):337-42. doi:10.1016/j.saa.2010.10.017. https://doi.org/10.1016/j.saa.2010.10.017.

28. Zahid. HC, Arif M, Muhammad AA, Claudiu TS. Metal Based antibacterial and antifungal agents: Synthesis, Characterization, and In vitro Biological evaluation of $\mathrm{Co}(\mathrm{II}), \mathrm{Cu}$ (II), Ni (II), and Zn (II) complexes with Amino acidderived Compounds, Bioinorganic Chemistry and Applications. 2006 (2006) 1- 13. DOI 10.1155/BCA/2006/83131; https://doi.org/10.1155/ BCA/2006/83131.

29. Sambrook J, Fritsch EF. Maniatis T, Molecular cloning, A laboratory Manual, second ed., Cold Spring Harbor Laboratory, Cold Spring Harbor, New York, 1989.

30. Meyer BN, Ferrigni NR, Putnam JE, Jacobsen LB, Nichols DE, McLaughlin JL, Planta Med. 45 (1982) 31-34.

31. Finney DJ, Probit Analysis, third ed., Cambridge University Press, United Kingdom, 1971.

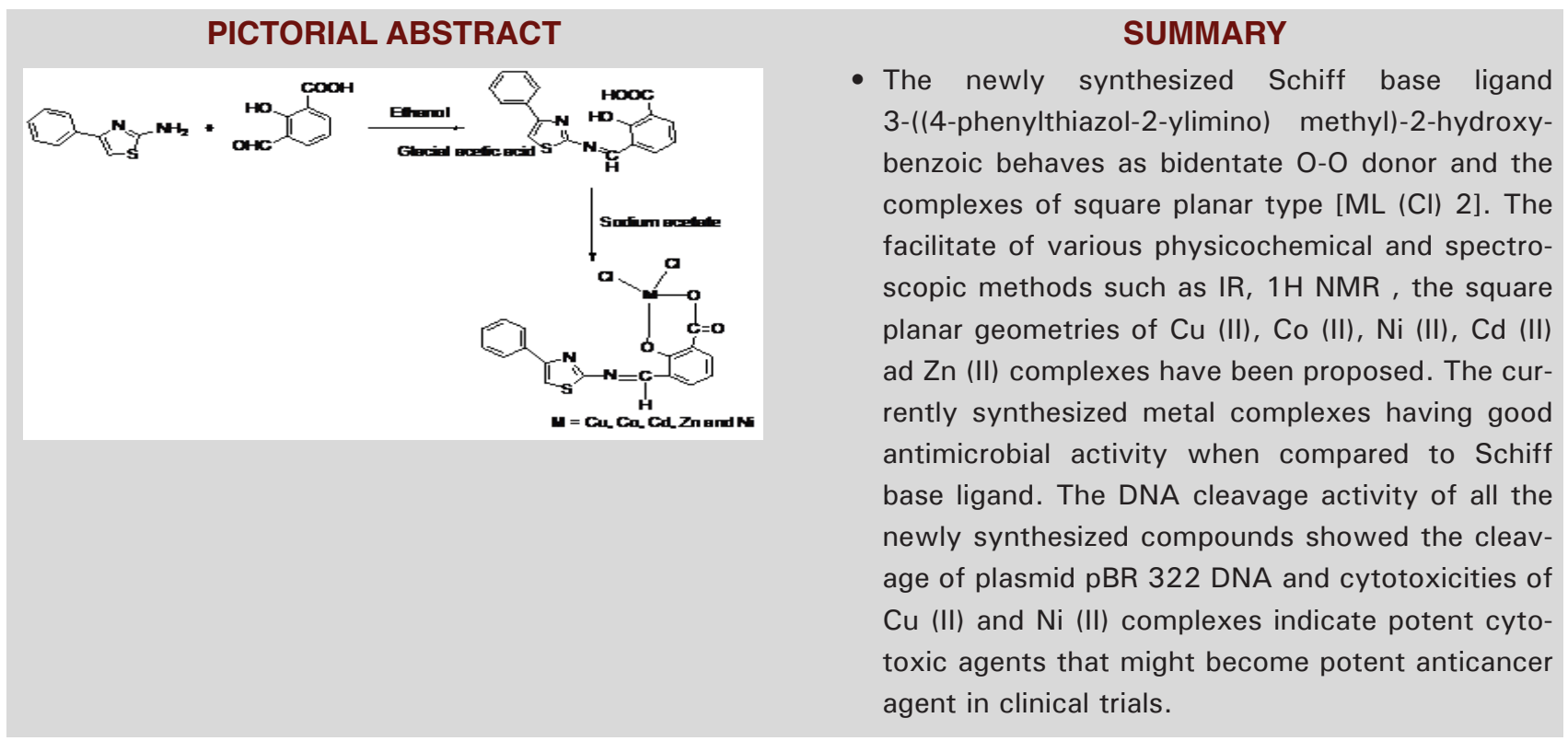




\section{About Authors}

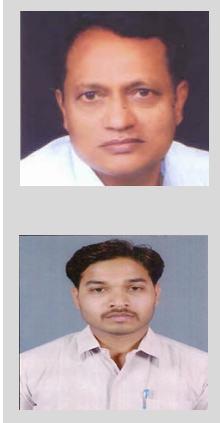

Dr. Basavaraj M. Kalshetty: Working as Associate Professor and Head of Department of Chemistry, BLDE's Science College Jamkhandi. Bagalakoti District, Karnataka State, India. He has number research publication in national and international journals.

Shambuling Karabasannavar: Working as Assistant Professor and Head of Department of Chemistry, Biluru Gurubasava Mahaswamiji Institute of Technology, Mudhol, Bagalakoti District, Karnataka State, India. He has 4 paper publications in international journals. Currently, he is pursuing PhD in Bharathiar University, Coimbatore, Tamilnadu, India.

Cite this article: Karabasannavar S, Allolli P, Shaikh IN, Kalshetty BM. Synthesis, Characterization and Antimicrobial Activity of some Metal Complexes Derived from Thiazole Schiff Bases with In-vitro Cytotoxicity and DNA Cleavage Studies. Indian Journal of Pharmaceutical Education and Research. 2017;51(3):490-501. 